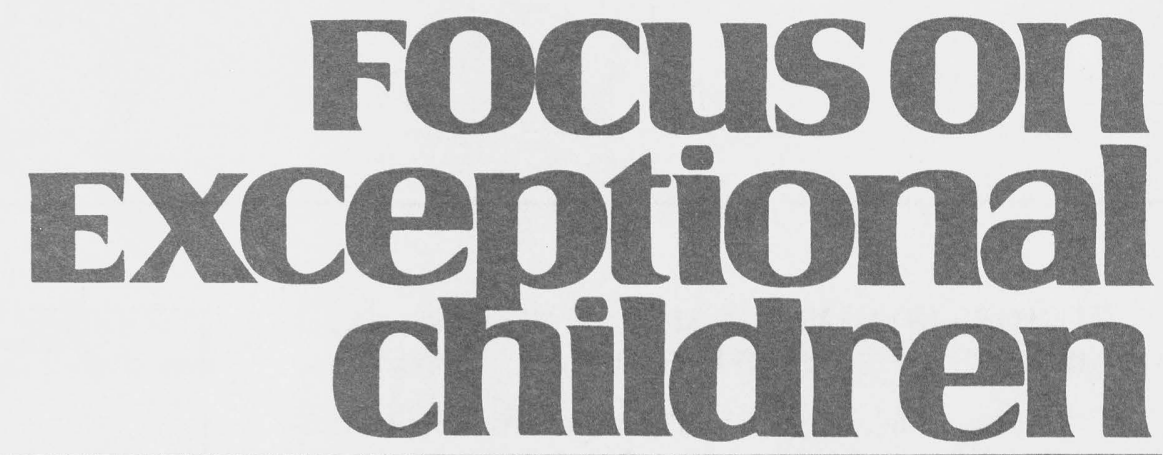

\title{
Selecting Instructional Interventions for Students with Mild Disabilities in Inclusive Classrooms
}

\author{
Marie C. Keel, Harry L. Dangel, and Sherie H. Owens
}

Of the many changes taking place in the field of education, one of the most significant is the movement toward inclusion (McLeskey, Henry, \& Hodges, 1998). Students with mild disabilities are being served in the general education classroom to a greater extent. In addition to students with identified disabilities, many students are considered at risk for disabilities. To provide effective instruction for this wide array of students, general educators must be armed with the knowledge and skills to provide assessment and intervention strategies that are potent, yet efficient enough to be implemented in the general education classroom.

Research evidence on effective strategies for increasing the academic achievement of students with mild disabilities in inclusion classes is limited (Fisher, Schumaker, \& Deshler, 1996). Relatively few studies have been conducted in inclusion settings, and the results are often disappointing and meager (Baker \& Zigmond, 1995; Zigmond et al., 1995). In a multi-state study of the effectiveness of restructuring schools to provide effective inclusion programs, nearly half of the students with mild disabilities continued to fall farther behind (Zigmond et al., 1995).

Although many texts are devoted to inclusion practices (Kochhar \& West, 1996; McCoy, 1995; Meyen, Vergason, \& Whelan, 1996; Stainback \& Stainback, 1990, 1992, 1996; Thousand, Villa, \& Nevin, 1994; Villa, Thousand, Stainback, \& Stainback, 1992; Wang, 1992; Zionts, 1997), few provide specific information regarding academic interventions for students with mild disabilities in the general education classroom. Lawrence (1988) does provide some basic guidelines for teachers, such as using a set schedule, developing clear rules and expectations, being consistent, providing clear directions, structuring transition times, and developing positive relationships with parents. Some instructional strategies recommended for inclusion include, but are not limited to, direct instruction for the acquisition of new skills, peer tutoring, cooperative learning, and self-instructional strategies (Lawrence, 1988; Vergason \& Anderegg, 1991). In this article we will discuss inclusion intervention strategies and provide a rationale for each.

Marie Keel and Harry Dangel are faculty members and Sherie Owens is a doctoral student in the Department of Educational Psychology and Special Education at Georgia State University. 


\section{FACTORS INVOLVED IN SELECTING APPROPRIATE INTERVENTIONS}

The extent to which general educators make modifications to accommodate the needs of students with mild disabilities (as well as other at-risk learners) is based primarily on the extent to which teachers view an intervention as acceptable (Bender \& Ukeje, 1989; Martens, Peterson, Witt, \& Cirone, 1986; Whinnery, Fuchs, \& Fuchs, 1991). The extent of acceptability is based on (a) the perceived appropriateness of the intervention to the classroom, (b) the amount of teacher time required, (c) the skill level required of the teacher, and (d) the possibility of any negative effects on other students. Based on these considerations, a model has been provided for selecting interventions that takes into account three factors: content, control, and efficiency (see Figure 1). These three factors must be taken into account as decisions are made concerning appropriate interventions for students with mild disabilities in inclusive classrooms.

\section{Content}

When selecting interventions for students with mild disabilities, teachers must consider whether this is a management

\section{Focuson
Exceptional
children}

ISSN 0015-511X FOCUS ON EXCEPTIONAL CHILDREN (USPS 203-360) is published monthly except June, July, and August as a service to teachers, special educators, curriculum specialists, administrators, and those concerned with the special education of exceptional children. This publication is annotated and indexed by the ERIC Clearinghouse on Handicapped and Gifted children for publication in the monthly Current Index to Journals in Education (CIJE) and the quarterly index, Exceptional Children Education Resources (ECER). The full text of Focus on Exceptional Children is also available in the electronic versions of the Education Index. It is also available in microfilm from Xerox University Microfilms, Ann Arbor, MI. Subscription rates: Individual, $\$ 30$ per year; institutions, $\$ 40$ per year. Copyright (c) 1999, Love Publishing Company. All rights reserved. Reproduction in whole or part without written permission is prohibited. Printed in the United States of America. Periodicals postage is paid at Denver, Colorado. POSTMASTER: Send address changes to:

$$
\begin{gathered}
\text { Love Publishing Company } \\
\text { Executive and Editorial Office } \\
\text { P.O. Box } 22353 \\
\text { Denver, Colorado } 80222 \\
\text { Telephone (303) 221-7333 }
\end{gathered}
$$

Edward L. Meyen University of Kansas

\section{Glenn A. Vergason} Georgia State University

Richard J. Whelan

University of Kansas Medical Center
Thomas S. Love Associate Editor

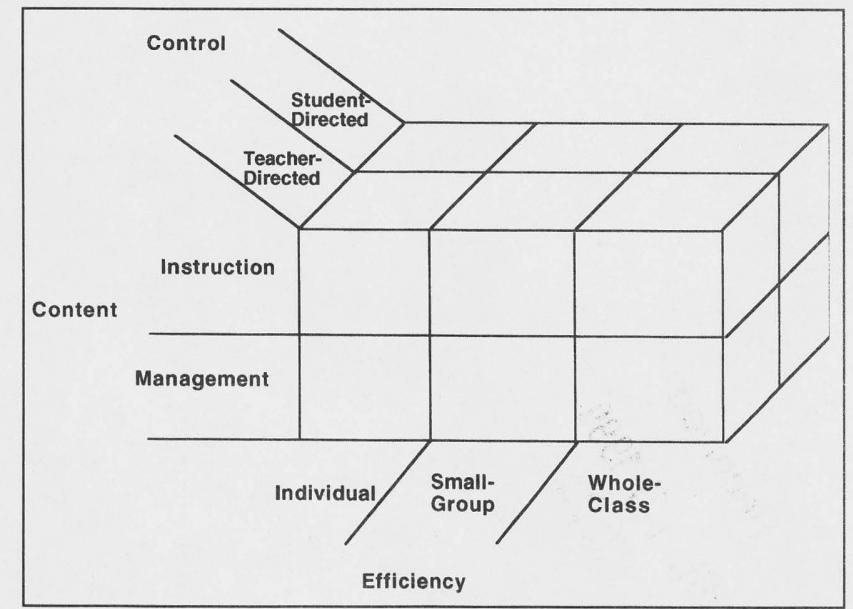

FIGURE 1

Model for Selecting Interventions for Inclusive Classrooms

problem or an instructional problem. Management is concerned with classroom behavior, social skills, and task completion. Instructional problems stem from students' difficulties in acquiring, maintaining, and generalizing academic skills. This review explores strategies for dealing with instructional problems. Readers who are interested in classroom management strategies should review the literature related to specific management concerns.

\section{Control}

Once the content of the problem has been determined, the teacher may choose to use interventions that are either primarily teacher-directed or primarily student-directed. Teacher-directed interventions place the teacher at the center of the intervention. The teacher makes decisions regarding the strategy to be used, provides models and demonstrations of the strategy, directs students in practice, and monitors students' successful use of the strategy. These interventions are most appropriate when they are used at the acquisition stage of learning and have been demonstrated to be effective with students who have mild disabilities (Mercer \& Mercer, 1998).

Student-directed interventions place the student at the center of the intervention, in which students are taught to use self-regulation procedures. Graham, Harris, and Reid (1993) defined self-regulation as an individual's ability to regulate his or her own behavior. Self-regulation training is an appealing means of promoting.independent academic and behavioral improvement in inclusive settings (Garner, 1992). Learning to use self-regulation procedures often increases task engagement, which in turn facilitates learning and also may decrease off-task behavior (Dunlap \& Dunlap, 
1989; Garner, 1992). More important, self-regulation techniques enable learners to monitor and regulate their own academic performance (Graham et al., 1993).

\section{Efficiency}

Efficiency is a principal concern in the general education environment because of the large number of students served in the classroom. Interventions that require implementation with individual students are extremely time-intensive for the teacher and may have to be considered as a last resort. Interventions that are either small-group or whole-class centered typically provide a more efficient means of instruction.

The decision regarding the choice from individual, smallgroup, or whole-class intervention often depends on the severity of the problem. As teachers determine whether to implement teacher-directed or student-directed strategies, they also must determine the appropriateness of implementing the strategies with the whole class, a small group, or individually.

\section{TEACHER-DIRECTED INTERVENTIONS VERSUS STUDENT-DIRECTED INTERVENTIONS}

The choice to use teacher-directed or student-directed approaches need not be an either/or decision. Because the instructional process involves multiple stages that move from initial acquisition through proficiency, maintenance, and generalization, a blend of relatively more teacherdirected interventions followed by those with a more studentdirected emphasis may offer an advantage. The research evidence shows that teacher-directed methods are powerful tools for teaching and managing students with learning and behavior problems (Gersten, 1998). These must be included in the arsenal of techniques used in inclusive settings. Studentdirected techniques also have a complementary role.

When practice beyond initial mastery and generalization to other tasks is important, student-directed techniques are a viable option in providing focused practice and drill. Peer tutoring, technology-mediated instruction, and self-regulation strategies offer useful procedures for application (e.g., Delquadri, Greenwood, Whorton, Carta, \& Hall, 1986; Fuchs, Fuchs, Mathes, \& Simmons, 1997; Graham et al., 1993; Greenwood, Delquadri, \& Hall, 1989; Mathes, Grek, Howard, Babyak, \& Allen, 1999; Stevens, Blackhurst, \& Schuster, 1991; Wirtz, Gardner, Weber, \& Bullara, 1996)

Educators should be guided in their selection of these tools by their knowledge of the instructional principles that have been proven effective for students with disabilities. For example, the integrated review of critical factors for teaching students with mild disabilities by Christenson, Ysseldyke, and Thurlow (1989) provides an excellent foundation for examining and selecting instructional procedures for promoting learning that can be applied regardless of the setting in which a student is served. These authors identify ten instructional factors essential for students with mild disabilities:

1. Effective classroom management;

2. A sense of positiveness in the school environment;

3. An appropriate instructional match;

4. Clearly stated teaching goals and expectations;

5. Lessons that follow clear, specific procedures;

6. Individual instructional support;

7. Sufficient academic time that is used efficiently;

8. High opportunities to respond;

9. Active monitoring of student progress and understanding;

10. Frequent and appropriate evaluation of student performance.

These characteristics should be part of both teacher-directed and student-directed programs.

\section{TEACHER-DIRECTED INTERVENTIONS}

Many teacher-directed interventions have been demonstrated to be effective with students with mild disabilities and those identified as at risk for disabilities. Few studies have actually been conducted in inclusive classrooms. Therefore, in this section we review interventions that may be used appropriately in inclusive classrooms. The teacherdirected interventions reviewed here may be implemented either with the whole class or in small groups.

\section{Direct Instruction}

Direct instruction is a system of teaching that has been demonstrated to be effective with a range of students (Adams \& Engelmann, 1996) including those considered to be disadvantaged (Fredrick, Keel, \& Neel, in press; Kaiser, Palumbo, Bialozor, \& McLaughlin, 1989; Lum \& Morton, 1984; Robinson \& Hesse, 1981; Tarver \& Jung, 1995) and those with mild disabilities (Anderson \& Keel, in press; Darch, 1989; Darch \& Carnine, 1986; Kelly, Gersten, \& Carnine, 1990; Kuder, 1990, 1991; Lloyd, Cullinan, Heins, \& Epstein, 1980). The components of direct instruction include explicit step-by-step teaching procedures that account for student mastery, immediate feedback, practice, and gradual fading from teacher direction. Direct instruction programs are available across a wide variety of subject areas including reading, mathematics, written language and reasoning skills, oral language, and spelling.

Students who are explicitly taught reading decoding skills are more likely to be successful readers (Chall, 1988; 
Kameenui, 1985). Carnine, Silbert, and Kameenui (1997) provide suggestions for teachers who seek ways to improve teaching using direct instruction strategies. These authors offer guidance on how to organize and design explicit reading programs as well as presentation techniques. First, they suggest focusing on teaching letter sounds as they are symbolized by individual letters, which are the smallest units of decoding.

Second, Carnine et al. recommend teaching students to sound out words before teaching them to read words as whole units. They argue that, by teaching students these skills, students are afforded a strategy that allows them to decode a variety of words, which multiplies with each newly acquired sound.

Third, they recommend presenting new words in isolation before introducing them in context. This enables students to attend to the letter combinations and read the words using only those cues, as opposed to using picture or context cues.

Fourth, they recommend that students focus on both accuracy and fluency. Students are expected to read each word correctly, quickly, and with expression.

Direct instruction also may be used to teach math skills (Stein, Silbert, \& Carnine, 1997). Stein and her colleagues suggest that after the teacher has determined the instructional objectives, an explicit instructional strategy should be designed that can be incorporated into the students' daily mathematics instruction. In designing an instructional strategy, the teacher will need to first determine the prerequisite skills necessary to meet the stated objectives. The skills then have to be sequenced so that preskills are taught prior to the strategy; easier skills are taught before introducing more difficult ones; and skills and information that may be confused are not presented consecutively.

\section{Precision Teaching}

Precision teaching is a method that provides a systematic means of monitoring student performance (Mercer \& Mercer, 1998). It requires the teacher to adjust the curriculum constantly in such a way that each student receives the maximum benefits of instruction. Lindsley (1991) describes precision teaching as making changes to the curricula based on student learning. Learning is measured through systematic use of recording devices, such as daily celeration charts, on which student responses are plotted and observed. Some research indicates that the most effective way to use the changes that precision teaching offers is in combination with the materials from direct instruction (Johnson, 1989; Maloney \& Humphrey, 1982).

Precision teaching has been used successfully in instructing students with mild disabilities in the mainstream setting. For example, through precision teaching, fluency and accuracy on vocabulary assessments increased for $70 \%$ to $91 \%$ of 694 students, 125 of whom were identified as having learning disabilities (Stump et al., 1992). Precision teaching was effective in teaching physical science to seventh graders, regardless of ability or achievement level (Lovitt, Rudsit, Jenkins, Pious, and Benedetti, 1985).

Mercer and Mercer (1998) suggest that precision teaching probe or task sheets be developed that can be used to determine and monitor target behavior daily. The results of these data should be used to set instructional objectives. These objectives are used to facilitate instructional design. The teacher then uses the probes or task sheets to determine the effectiveness of the instructional program and to assist in making ongoing modifications as determined by the results of the daily data. Beck, Conrad, and Anderson (1995) provide a large number of ready-made probes or task sheets in their Basic Skill Builders collection.

\section{Time Delay}

Constant time delay (CTD) is a response-prompting procedure that has an extensive research base in which most of the studies have been conducted in a one-to-one setting. CTD has been shown to be both effective and efficient in teaching a variety of skills to learners with a range of disabilities. In a review of the CTD literature, Wolery and his colleagues (Wolery, Holcombe et al., 1992) analyzed the results of 36 studies and found that the procedure was successful in teaching discrete skills to $97.7 \%$ of the participants. In addition to the high success rate, errors by students with mild disabilities typically were less than $5 \%$ for all responses.

The CTD procedure is easily implemented in classroom settings. It is a near-errorless instructional strategy in which the teacher always gives a response prompt if the student waits for assistance in stating the correct answer. The response prompt used in the CTD procedure should be a controlling prompt; it should increase the probability of the student's giving a correct response. During initial trials the teacher presents the task direction, then immediately presents the controlling prompt. There is no delay between the task direction and presentation of the controlling prompt; thus, these trials usually are described as $0-s$ delay trials.

During subsequent trials, a fixed-delay interval (e.g., the number of seconds in which the teacher waits for a student response) is inserted between presentation of the task direction and the controlling prompt. This provides the student with the opportunity to respond without assistance when possible. A student who is unsure of the correct response may choose to wait until the teacher provides the controlling prompt.

The teacher reinforces correct answers given by the student both before and after the prompt, typically with verbal praise. If a student makes an error either before or after 
receiving the prompt, the teacher provides the correct answer and requires the student to repeat the response. The goal of the CTD procedure is for the student to consistently respond correctly to the task direction or target stimulus prior to presentation of the controlling prompt (Wolery, Ault, \& Doyle, 1992).

Most published reports of CTD describe teachers working with individual students. One method for improving the efficiency of the CTD procedure is to implement it in group settings. Several researchers have indicated that group instructional arrangements are at least as effective as individual instruction (Alberto, Jobes, Sizemore, \& Doran, 1980; Browder, Schoen, \& Lentz, 1986-1987). Several previous studies have explored successfully the use of CTD with groups of students with mild disabilities (Keel \& Gast, 1992; Winterling, 1990; Wolery, Ault, Gast, Doyle, \& Mills, 1990, Wolery, Cybriwsky, Gast, \& Boyle-Gast, 1991). Teaching students in groups provides the potential for students to acquire information that is presented to other members of the group. This has been described in the literature as observational learning (Browder et al., 1986-1987).

A second means of improving instructional efficiency with the CTD procedure is through incidental learning. Incidental learning refers to the acquisition of related, non-target information that is presented within the instructional context (Wolery, Ault, \& Doyle, 1992). This related information may be presented in either antecedent or consequent events. Studies conducted with students who have mild disabilities have investigated the incidental acquisition of spelling (Gast, Doyle, Wolery, Ault, \& Baklarz, 1991; Keel \& Gast, 1992; Shelton, Gast, Wolery, \& Winterling, 1991; Winterling, 1990), word definitions (Keel \& Gast, 1992; Shelton et al., 1991), and science and social studies facts (Wolery et al., 1991). Both observational and incidental learning appear to have potential to enhance the instructional efficiency of the CTD procedure as students acquire information that is not directly taught.

\section{Story Maps}

Sorrell (1990) described story mapping as a technique to provide or build upon prior knowledge or schema; it assists students in interpreting and comprehending new information. Story mapping instructs students to attend to relevant parts of the story using a set framework. This technique can effectively guide students through text and assist in reading comprehension by providing an organization of text structure. Idol (1987) and Idol and Croll (1987) used story maps successfully to teach reading comprehension of narrative stories. Students who were identified as poor readers were taught to successfully use an outline that required them to identify the setting, problem, goal, events, or actions that contribute to the goal, and the outcome or resolution of each passage.
The authors emphasize the importance of preparing students by familiarizing them with the purpose of the story map and how to use the tool correctly. The teacher may spend a number of days reading narratives, stopping at points in the stories that pertain to the individual components of the story map. The teacher then can ask students to identify which component the specific portion of the text relates to, thereby allowing for immediate feedback. Eventually students will fill out the story map independently with less prompting.

\section{Advance Organizers}

An advance organizer is a verbal or written technique used to provide students with an overview or preview of material to be presented. It is intended to activate prior knowledge about a topic, as well as providing information concerning the material to be presented (Ausubel, Novak, \& Hanesian, 1978). The use of advance organizers benefits students with mild disabilities in the typical classroom (Lenz, Alley, \& Schumaker, 1987). Darch and Gersten (1986) observed an increase in comprehension of critical concepts during content-area instruction with the use of advance organizers. They suggest that an effective advance organizer

— informs the student of the purpose of the organizer

- clarifies the actions of the teacher and the student

- identifies and explains the topics

- identifies subtopics and concepts that should be addressed

— provides background information

- provides rationales for teaching the lesson

— introduces unfamiliar terms or words

- provides an organizational framework

- states desired results of the lesson.

Advance organizers may be provided in the form of outlines, study guides, oral presentations, or other formats (Reynolds \& Salend, 1990). For example, Bulgren, Schumaker, and Deshler (1988) designed and evaluated the effectiveness of concept diagrams when combined with a concept teaching routine. The teachers developed concept diagrams to correspond to a particular lesson. First, the teacher was to select a specific concept. Next, the teacher prepared a list of critical words or phrases directly related to the concept. Then the items were categorized into nonexamples and examples of the key concept. Finally, the teacher completed a concept diagram by inserting these items into the appropriate areas on the diagram.

After plotting the concept diagram, teachers presented information using the concept teaching routine. This routine 
included providing an advance organizer; allowing students to supply a list of key words in relation to the lesson; naming and defining the concept; discussing "always," "sometimes," and "never" characteristics of the concept; discussing one example and one non-example of the concept; linking each to the characteristics; evaluating possible examples and non-examples to decide if they are components of the concept; and providing a post-organizer. Results indicated that the performance of students with and without learning disabilities increased on assessments and in notetaking skills when teachers used the concept teaching routine using concept diagrams.

\section{STUDENT-DIRECTED INTERVENTIONS}

A review of the longitudinal research suggests a number of factors that seem to be associated with successful inclusion in life by students who had been served in classes for students with learning difficulties. Factors such as the ability to set realistic goals and plans, to deal with frustration, to overcome problems, and to be persistent are related to successful post-school adjustment (Spekman, Goldberg, and Herman, 1992; Werner, 1993). To assist students in developing a more self-directed outlook, educators and students might benefit from considering the following recommendations (Schunk \& Zimmerman, 1994):

1. Begin by focusing on a content area in which the student is committed to improving.

2. Establish with the student a well-defined goal that is easily monitored.

3. Emphasize self-monitoring some part of behavior related to the goal.

4. Establish and teach a routine for working on the goal that includes covert responses with abundant repetition to promote early success.

5. Assist students in overlearning the steps of the routine to assure application.

6. Teach routines that are content-specific with clear applications to the student problem to ensure the likelihood of generalization.

7. Reduce the difficulty of content during the early stages of establishing the program so the student can focus on self-regulation, including self-monitoring and self-instruction, rather than the curriculum.

8. Include a focus on attribution from the beginning of the student's work by emphasizing the link between commitment, effort, and progress.

Educators are searching continually for instructional programs that prepare students to master the demands of the curriculum while they become more independent and less reliant on others (Johnson \& Johnson, 1999). Teachers of students with mild disabilities, when successful, lessen the time spent on planning, structuring, implementing, monitoring, and modifying programs while they simultaneously assist students to function on their own in general education classes and in the general society. Educators are especially challenged to identify and implement programs that enable students with disabilities who are served in inclusion programs to acquire the necessary self-direction and independence to fully benefit from the general education instructional program.

Use of the term student-directed captures the image of an independent, self-reliant student who successfully copes with the demands of the general education classroom. As with most interventions with students who have disabilities in academic and behavioral areas, however, the evidence for effective and efficient interventions in inclusive settings remains elusive.

Notwithstanding the lack of systematic solutions for serving students with mild disabilities in inclusion classes, some research documents instructional procedures that promote independence (e.g., Borkowski \& Thorpe, 1994; DiGangi, Maag, \& Rutherford, 1991, Dunlap \& Dunlap, 1989; Graham et al., 1993). The student-directed interventions are best viewed as tools that might be selected when a student is ready to move from a more teacher-directed instructional format to one in which the student's role is more active.

The student-directed interventions described in this article are most effective when they are used as part of a continuum in which the teacher determines how the curriculum is structured and presented and what instructional activities are most appropriate for achieving curricular objectives. Over time, the student directs more of the established routines for interacting with the curriculum to ensure mastery of the skills and content that have been presented.

Ideally, a review of student-directed instructional programs would be filled with empirical research conducted in general education classes with students who have academic or behavioral problems in which the intervention was student-directed and effective. For example, Wirtz et al. (1996) determined that six students with low achievement in spelling improved their spelling grades and maintained the ability to spell the words when using a self-correction procedure on the general education class spelling curriculum within their third grade class.

In a review of validated inclusive practices on academic improvement, however, Fisher et al. (1996) noted a lack of research on interventions that have been conducted with special education students within general education classrooms. They also reported that the intervention strategies 
that have been researched have had significant limitations, including not producing socially significant results for all students and sometimes not affecting the academic performance of students with mild disabilities positively. Interventions with some evidence of producing positive results are overwhelmingly teacher-directed, with the exception of research on aspects of peer tutoring.

\section{Student-Directed Task Engagement}

Effective student-directed interventions must consider the role of managing the student's behavior as an initial concern in promoting academic achievement (Christenson et al., 1989). Students with academic difficulties must attend to instruction, complete assignments, and maximize their opportunities to respond. Research on self-management procedures can be grouped into four areas (Nelson, Smith, Young, \& Dodd, 1991):

\section{Self-monitoring or self-recording}

2. Self-assessment or self-evaluation

3. Self-instruction

\section{Self-reinforcement}

A behavioral view of self-regulation emphasizes the importance of having students learn to postpone an immediate reward in return for a more appropriate (and hopefully more satisfying) reward at a later time (Mace, Belfiore, \& Shea, 1990). Self-regulation of behavior involves identifying behavioral alternatives, choosing reinforcers for the behavioral alternatives, and managing the delivery of delayed consequences.

A number of studies have demonstrated that self-monitoring and self-recording improve classroom behavior of students in special education programs (Hughes, Korinek, \& Gorman, 1991; Nelson et al., 1991). For example, self-monitoring has been shown to increase on-task behavior of students served in programs for mild disabilities (Blick \& Test, 1987). This was done for three separate groups of four students each within a special class. The authors used a set of audiotapes to cue students to record whether they were or were not on task. The cues consisted of the verbal cue, "Record," provided at approximately 10-minute intervals. During the intervention phases, students marked a monitoring sheet with a "+" or "0" to indicate whether they had been on-task. The teacher checked on-task performance at intervals between the verbal cues.

In this study, students' on-task behavior increased to between $80 \%$ and $91 \%$ for the 12 students. The positive impact of self-monitoring and self-recording has been replicated by other researchers (e.g., DiGangi \& Maag, 1992; DiGangi et al., 1991; McLaughlin, Krappman, \& Welsh, 1985; Osborne, Kosiewicz, Crumley, \& Lee, 1987; Prater, Joy, Chilman, Temple, \& Miller, 1991).
The efficacy of a self-recording strategy has been demonstrated with a broader array of behaviors as well. Four middle school students who were receiving special education services in a resource room were taught to use a self-recording procedure to promote a set of discrete behaviors (Clees, 1994-1995). General education mathematics teachers identified the students as not meeting the teachers' expectations for appropriate behavior and having deficient organization skills. The specific target behaviors developed with the assistance of general educators in social studies and science included:

1. Brings necessary materials to class.

2. Begins class on-task.

3. Turns in completed homework.

4. Completes all classwork.

5. Writes homework in assignment book.

The special education teacher trained students individually to self-record whether their behavior in class had met the teacher's expectation statement. Training took 10 to 15 minutes per student. After the training, students were instructed to keep track of what they needed to do by taking the form containing the schedule of teachers' expectations to each class and completing it and turning it in to the special education teacher at the end of the day. Students simply marked "yes" or "no" as to whether each of the five expectations was met. Two of the students were given an abbreviated version of the expectations form, containing key words rather than the whole phrase.

General education teachers' ratings indicated that all students' behaviors improved significantly (near 100\% for three of the four students) when they self-recorded whether they had met the expectations on the form. Even when the self-recording phase ended, the students maintained appropriate behavior at approximately the same level of compliance. The attractiveness of this self-recording approach is its effectiveness and efficiency. Not only did the students' behavior improve across general education classes on behaviors that the general educators themselves identified as problems, but the procedure also required little training time, maintained the behavior change after the intervention ended, and required only minimal participation by general educators.

In an attempt to isolate the relative impact of studentdirected strategies on improving the behavior of students with behavior problems, DiGangi and Maag (1992) compared combinations of self-monitoring, self-evaluation/selfreinforcement, and self-instruction to reduce inappropriate verbalizations with three junior high students receiving mathematics instruction in a special education resource room. Self-monitoring involved making tally marks on one 
side of an index card for appropriate verbalizations and on the other side for inappropriate verbalizations. The selfevaluation/self-reinforcement strategy required students to ask, "How is this working out? How am I doing?" When students thought they were doing well, they were instructed to tell themselves, "I'm doing a great job."

Self-instruction training involved first modeling for students and then having students overtly, then covertly, repeat a series of self-instruction commands (i.e., "Do I understand what I'm working on? What don't I understand? Should I raise my hand or talk out loud?"). The subsequent drop in inappropriate verbalizations indicated that the training was effective. Combining self-monitoring and self-instruction enhanced the improvement for these students.

Some evidence indicates that the application of self-monitoring behavior can be extended through the use of the videotaping. Buggey (1999) demonstrated how using 3- to 5 -minute segments of videotapes that show the student exhibiting the desired behavior can be an effective tool for developing and reinforcing appropriate social skills. Tapes of the student that provide a model of his or her own appropriate behavior, as compared to tapes of others modeling the behavior, have had a direct and positive impact on behavior change. Buggey notes that the source of the videotape model might be drawn from role-playing settings which recreate problematic situations and in which the student is guided to display the appropriate behavior or from tapes in which the student displays the desired behavior in naturally-occurring situations.

\section{Student-Directed Instruction}

How does the teacher of students with mild disabilities in an inclusion setting order and implement student-directed strategies that promote student-direction and independence? Students with mild disabilities have difficulty with learning tasks presented in inclusion classes (Fisher et al. 1996). Many of these learning problems are related to difficulties in applying appropriate strategies for dealing with the learning tasks. Research provides many examples of how students have difficulty evaluating the requirements of a learning task, selecting and using the most effective strategies, and evaluating the appropriateness of their work (Graham et al., 1993; Wong, 1996).

Much has been written about the value of providing students who have disabilities with metacognitive strategies to make them more independent learners. Some evidence, however, indicates that teaching general metacognitive strategies in which a student judges the requirements of a task and the extent to which he or she possesses the skills to complete the task successfully have limited value for students with disabilities (Hirsh, 1996). Teaching self-management skills associated with metacognition must be balanced with systematic instruction of the content in which the strategy is to be applied. Metacognitive strategies are learned and applied most easily in areas in which the student has thoroughly mastered the content, rather than as an alternative or substitute for content mastery (Hirsh, 1996; Siegler, 1995).

Hirsh (1996) cautioned that overemphasis on general metacognitive strategies may result in (a) interference in the orderly development of adaptive problem-solving strategies, (b) severe opportunity costs by usurping subject-matter instruction, and (c) the overload of working memory, thus impairing rather than assisting learning. He noted that the impact of these potential drawbacks is likely most severe for students who have learning difficulties.

A second caution in using a strategy approach to help students become more independent is sounded by Wong (1996) and Borkowski and Thorpe (1994). They have noted the importance of student motivation and attribution components in preparing students to become competent achievers. Although students with disabilities might have a history of failure, they must be committed to the importance of their own efforts rather than attributing success or failure to a disability label, being favored by the teacher, or misfortune. The motivation for achievement must be based on the twin concepts of valuing success in school and expecting to be able to attain it (Adelman \& Taylor, 1993).

The Wirtz et al. (1996) study cited here is worth examining as an introduction to how student-directed skills might be developed. They implemented a student-directed intervention to improve spelling within the context of a general education class. They taught six students with low achievement in spelling to listen to their spelling words using cassette players with headsets while they looked at the words printed in a column. The students then folded the column so the words could not be seen, listened to the tape with the words again, and stopped the tape while they attempted to write each word in the second column. At the end of the list, the students checked to see whether each word in the second column was spelled correctly and used proofreading marks to correct each error and write the corrected spelling in the third column. They gave words spelled correctly in the second column a checkmark in the third column. These students continued to practice spelling and self-correcting their work until the end of the 20-minute period.

This self-directed procedure was compared to the traditional approach of having students do a different activity with the words for 20 minutes a day. Students alternated between the two procedures each week. The scores on the end-of-week spelling tests, biweekly maintenance tests, and a generalization probe at the end of the study resulted in approximately four more words spelled correctly when students used the self-directed method as compared to the traditional method. 
All students also received higher grades on the weekly spelling test when they used the self-directed method, and they indicated that they preferred this approach to the traditional method of study. Although these students had not been labeled as eligible for special education services, their improved performance is encouraging because they became self-regulated learners with words from the general education curriculum within the context of the third-grade class.

The process of self-monitoring academic performance in the Wirtz et al. (1996) study provides a parallel to selfmonitoring of behavior, described earlier. Recognition of a disparity between the desired and the existing behavior is the cornerstone of any program of self-directed student behavior. Spelling words offer a clear, permanent model against which the student's written performance can be compared; therefore, spelling may be an ideal curriculum area in which to introduce self-regulation skills.

A teacher in an inclusion class could not only implement the procedures used in this research but also could easily include other components of self-regulation. For example, once the self-directed checking procedures are mastered, students might set goals for the number of words to be mastered and record the results. Or students might sort words into stacks of hard and easy words and adjust the amount of practice based on difficulty of words and practice results.

Most students with mild disabilities have deficits in reading, and instruction in reading accounts for a major part of special education interventions for these students. Research has demonstrated the value of using self-questioning (Wong \& Jones, 1982), metacognitive strategies such as reciprocal teaching (Palincsar \& Brown, 1984), strategy instruction such as DISSECT for word recognition (Lenz, Schumaker, Deshler, \& Beals, 1984), paraphrasing for reading comprehension (Schumaker, Deshler, \& Denton, 1984), and PARTS for content area textbooks (Ellis, 1994).

Wong (1996) explained, however, that research on metacognitive strategies in reading peaked in the 1980s and researchers are currently focusing more on writing and mathematics than on reading. Some of this shift is understandable given the nature of the task of reading and the components that seem to facilitate student-directed interventions. Reading is a receptive activity in that self-monitoring of discrete responses is more difficult than self-monitoring of writing numerals in arithmetic or spelling words. Although the implementation of strategies in reading is essential, self-regulation with students who have mild disabilities is probably best adopted with definitive, covert behaviors that are externally monitored and evaluated.

\section{Student-Directed Mnemonic Strategies}

Other evidence suggests that more complex self-regulation interventions implemented within general education can effectively promote the achievement of students with disabilities (Danoff, Harris, \& Graham, 1993).

These include SRSD, ITFITS, PLEASE, RPF-HECC, and TELLS Fact or Fiction.

\section{Self-Regulated Strategy Development (SRSD)}

Self-regulated strategy development (SRSD) is a cognitive strategy instructional program in which elements of self-regulation (i.e., goal setting, self-instruction, selfmonitoring, and self-evaluation) are taught within the context of instruction in story writing. Three students with LD and their matched normally achieving classmates all showed improvement in the quality of their writing and, for most, maintained and generalized this improvement. The instruction was provided to the whole class, with emphasis on learning and applying a multistep strategy that consisted of generating a story, including specific story elements, and putting the story on paper. A mnemonic device guided students to include important story elements:

Who (main character)

When (timeframe for the story)

Where (location)

What (What does the main character want?

What happens?)

How (How does it end?

How does the character feel?).

Explicit instruction and modeling of the strategy were critical elements in the program. Students were led from a teacher-directed format to one in which they collaboratively, then independently, set goals and used self-instruction and self-monitoring to practice and master the strategy (Danoff et al., 1993).

Results from the Danoff et al. investigation are important for several reasons. First, a systematic strategy was introduced and taught within a general education classroom in the context of the general education curriculum. Second, students with disabilities and their normally achieving classmates demonstrated significant improvement in their ability to compose stories. Third, the self-regulation skills and strategy were taught within a content area so that no separate instruction was needed to apply these skills in an isolated instruction context.

SRSD has been investigated over a number of years (e.g., Graham, 1990; Graham \& Harris, 1989; Graham \& Harris, 1994; Graham, Harris, MacArthur, \& Schwartz, 1991; Graham, MacArthur, \& Schwartz, 1995) and been demonstrated across students and settings to promote improved written composition and student self-regulation. Teachers using SRSD are successful at promoting the goal of moving 
systematically from effective teacher-directed instruction to student-directed instruction.

Teachers begin by explicitly modeling and teaching how to write, teaching strategy use, correcting written work, and gradually withdrawing direct teacher instruction as students become more and more independent with each component of the writing process (Graham \& Harris, 1994). The scaffolding process moves from an emphasis on teacherdirected multiple opportunities for correct responses and students memorizing steps in the strategy to student-directed strategy implementation and self-monitoring.

\section{ITFITS Keyword Mnemonic}

Another example of applying strategies to content areas that promote self-instruction stems from the work of KingSears, Mercer, and Sindelar (1992). They reported that adolescent students in special education learned science terms and definitions when they used the keyword mnemonic approach ITFITS. In two experimental conditions students in groups of 10 to 18 were taught to I (identify the term), $\mathrm{T}$ (tell the definition of the term), F (find a keyword), I (imagine the definition by doing something with the keyword), $\mathrm{T}$ (think about the definition doing something with the keyword), and S (study what you imagined until you know the definition).

For one group of students, the teacher imposed a keyword with an interactive illustration to show the relationship between the keyword and the definition to be learned. The second group of students was taught the strategy, but then after a week these students were required to generate their own keywords and interactive illustrations for the terms to be learned.

Results indicate that both of the experimental groups learned and retained more definitions than a control group that was simply taught the terms and definitions in a systematic manner. Although students who had to generate their own keywords and relationships reported that they had difficulty thinking of words and illustrations to facilitate recall of definitions, the success of these students in the induced condition offers promise for independent learning in inclusive settings.

\section{PLEASE Strategy}

The PLEASE strategy is used to improve students' ability to write paragraphs. Welch (1992) found this strategy to be effective in increasing metacognitive understanding of written expression in sixth-grade students who had been diagnosed with learning disabilities. The program consists of an instructional manual and a videocassette for teachers. The strategy teaches students to P (pick a topic, audience, and appropriate textual format); $\mathrm{L}$ (list ideas concerning the topic); $\mathrm{E}$ (evaluate the list); A (activate the paragraph using a topic sentence); $\mathrm{S}$ (supply sentences to support the topic); and $\mathrm{E}$ (end the paragraph with a concluding sentence and evaluate the finished product).

\section{RPV-HECC Cognitive Strategy}

A different view of training self-regulation skills comes from Montague's research on developing strategies for solving problems in mathematics (Montague, 1991, Montague, Applegate, \& Marquard, 1993). These investigations evaluated the relative effect of task-specific cognitive strategies and metacognitive strategies in mathematical problem solving. She established that middle school students could use successfully a combination of cognitive and metacognitive strategies to solve multiple-step word problems.

The cognitive strategy (RPV-HECC) included direct instruction on these steps: Read (for understanding), Paraphrase (your own words), Visualize (a picture or diagram), Hypothesize (a plan to solve the problem), Estimate (predict the number), Compute (do the arithmetic), and Check (make sure everything is right). Students were required to memorize the steps of the cognitive strategy intervention. On the other hand, in the metacognitive strategy training, students learned self-management skills to self-instruct (SAY), selfquestion (ASK), and self-evaluate (CHECK) for each of the seven components of the cognitive strategy. Montague's findings indicate that students with learning disabilities need considerable time to master the strategies and apply them to problems efficiently, that over time students seemed to benefit from first having instruction in the specific cognitive strategy, followed by the more general metacognitive strategy. Her results also indicate that students in the seventh and eighth grades were able to learn and apply the strategies, whereas students in sixth grade did not benefit from the strategy instruction. Her work also reinforces the importance of explicit teacher instruction as a part of training strategies and self-regulation skills (Wong, 1996).

\section{TELLS Fact or Fiction}

Sorrell (1990) described TELLS Fact or Fiction as a guided comprehension tool to prepare students for approaching reading assignments. Idol-Maestas (1985) successfully used this model to improve reading comprehension performance in students with learning disabilities. In teaching students to use TELLS Fact or Fiction, the teacher trains them to T (study the Title); E (Examine the text to determine the theme); L (Look for words that appear to be important); L (Look for words that appear to be difficult); S (identify the Setting); and finally, to decide whether the story is Fact or Fiction.

For example, before reading a passage, the teacher might have the students answer a question concerning one of the previous steps, such as "What does the title tell you about 
the story?" The teacher continues in this fashion until each step is completed. According to Sorrell (1990), a teacher may have to reserve approximately 15 minutes for this portion of the lesson.

\section{Cooperative Learning}

Collaborative strategies such as cooperative learning and peer tutoring are recommended as a means to increase the achievement of students with academic difficulties by promoting interdependence among a group of heterogeneous students (Harper, Mallette, Maheady, Parkes, \& Moore, 1993; Johnson \& Johnson, 1986; Peck, 1989; Slavin, 1990). Cooperative learning strategies require groups of students to work together. The students are usually grouped so higherachieving group members can assist students who are having academic difficulty.

\section{Student Teams - Achievement Division}

An example of a cooperative learning tool is the Student Teams-Achievement Division model (Slavin, 1990). After a traditional presentation of the material, students meet in assigned groups to review the material as a means of preparing for a quiz. In cooperative learning situations, students have to rely on each other to achieve a common goal. Thus, rewards are based on group performance (Peck, 1989).

\section{Jigsaw}

Jigsaw is a cooperative learning strategy in which students are responsible for a portion of the learning and teaching. Students are asked to research independently a specific portion of the lesson and be prepared to share it with their classmates (Brown, 1994). In this way, each student takes responsibility for a piece of the puzzle. Before presenting the jigsaw lesson, Brown (1994) suggests that teachers work closely with specialists within the domain of interest. After selecting a topic, it is divided into subtopics and distributed among members of each group. Each member is responsible for becoming an "expert" in his or her area. The students later regroup and exchange their findings.

\section{Peer Tutoring}

Across the years, research on peer tutoring has consistently yielded positive effects for promoting the achievement of students with learning problems. For example, Greenwood (1991) reported on at-risk students using classwide peer tutoring in general education in schools with histories of low achievement. These students spent more time academically engaged and had higher achievement on standardized tests in reading, mathematics, and language than students in a comparable school without classwide peer tutoring.

One way to reconceptualize the rationale for peer tutoring is by associating the elements of effective instruction with what happens during peer tutoring. Consider the list of factors listed earlier from Christenson et al. (1989). The structured interaction between a well trained tutor and a tutee not only can promote positive classroom management but also can increase efficient use of academic time. Peer tutoring, too, encourages teachers to design lessons that follow clear, specific procedures. Further, it encourages active monitoring of students' progress and understanding. Finally, peer tutoring provides extended individual instructional support and increased opportunities to respond.

Effective structures for implementing a classwide peertutoring program include both coaching and practice (Fuchs, Fuchs, Hamlett, Phillips, \& Karns, 1995; Phillips, Hamlett, Fuchs, \& Fuchs, 1993). In an investigation of the effectiveness of classwide peer tutoring on learning multiplication facts, tutor and tutee (or, in this investigation, coach and player) worked together in a 30-minute block. They progressed through an introduction, coaching (using a series of prescribed questions appropriate for the material to be learned), transition to practice, independent practice (both coach and player complete and score the practice worksheets), and completion.

An important part of the coaching process was the correction that coaches gave to players who made errors. The coach circled each correct digit; the player corrected incorrect digits, and the coach marked them with a triangle. If the player answered the third in a series of problems correctly, the player proceeded to work on additional problems while the coach monitored with an answer sheet and, in case of error, intervened with the prescribed questions to lead the player to the correct answer.

The clearly structured coaching/correction procedure in the Fuchs et al. peer tutoring studies applied the principles of effective instruction by using lessons that follow clear, specific procedures; providing individual instructional support; ensuring sufficient academic time and using it efficiently; providing opportunities to respond; and actively monitoring students' progress and understanding (Christenson et al., 1989). In this sense, "student-directed" refers to "other-directed" rather than self-directed.

This approach is most appropriate for students who have difficulty attending, who need guided practice and reteaching, and who have trouble monitoring their responses and making decisions on how to restructure a task following an incorrect or an inappropriate response. Activities that are appropriate for peer-direction are those requiring considerable repetition and practice along with corrective feedback, which may be effectively provided by a peer who has been trained to present, evaluate, correct, and record the responses of a classmate.

Further insight into the instructional dynamics of peer tutoring as a student-directed intervention can be gained by 
reviewing tutees' error patterns (Harper, Mallette, Maheady, Parkes, \& Moore, 1993). Although students with mild disabilities demonstrated significant improvement when spelling words were taught and practiced using classwide peer tutoring, those authors examined the possible relationship between the tutorial process and spelling words that had not been mastered. The authors ruled out the possibility that the teacher had failed to implement peer tutoring procedures properly, that students had not followed the procedure correctly, or that they had not practiced the misspelled words correctly. The authors, however, did discover that words misspelled on the Friday spelling test had been written at a significantly lower rate during the week. Students made errors on the words they practiced the least - an insight that should lead to corrective procedures and increased spelling achievement by emphasizing procedures such as error drills-focusing instruction and practice on items that were missed (Christenson et al. 1989).

\section{Technology-Mediated Instruction}

Technology-mediated instruction is a student-directed option in which presentation, guided practice, feedback, monitoring, and evaluation are provided using technology that is often, but is not limited to, a computer. The use of computers as a component of student-directed approaches deserves careful consideration. Computer-assisted instruction (CAI) provides an alternative to teacher-directed instruction for specific components of instruction. Although the computer may one day offer many options for providing instruction for students with disabilities, its major function continues to be a tool to provide additional practice and drill following teacher-directed instruction (Reynolds \& Salend, 1990; Torgesen \& Barker, 1995). For students with learning problems who are being served in general education classes, however, additional drill and practice is an important function. In fact, providing these students with the opportunity for more repetition in mastering knowledge and skills and developing greater fluency is an important benefit for teachers trying to meet students' instructional needs (Freeman \& McLaughlin, 1984; Torgesen \& Barker, 1995).

Two examples in which computers were employed to provide additional practice for students with learning disabilities are Okolo's (1992) work in mathematics and Torgesen, Waters, Cohen, and Torgesen's (1988) research in reading. Although neither study was done within a general education class with the standard curriculum, each offers evidence that repetition and drill with a computer can improve mastery of basic skills.

Okolo showed that a game format as well as a drill format promoted student mastery of arithmetic facts. She found that all students, whether they scored as having high or low attitudes toward mathematics, benefited from both the game and drill formats.
More than a decade ago, Torgesen et al. used three presentation variations (visual, auditory, and visual/auditory combined) to teach sight words to students with learning disabilities. Each of the presentation formats resulted in increased accuracy and fluency in recognizing sight words and confirmed that students with learning disabilities can effectively use programs that use synthesized speech to master sight words.

Edwards, Blackhurst, and Koorland (1995) investigated using a computer program to coordinate a constant time delay (CTD) procedure for teaching the spelling of abbreviations to four students with mild disabilities. As noted above, CTD is a powerful procedure for teaching basic factual knowledge. A considerable amount of teacher time is required, however, to present, evaluate, and record a student's progress and to provide corrective feedback when a student makes an incorrect response.

Edwards et al. demonstrated that a computer with voice synthesizer could present the word to be abbreviated, check the typed responses, and provide appropriate corrections and feedback. The adolescents who participated in the study made instant and dramatic improvement using the computer-managed CTD. Other investigators, too, have demonstrated that multiplication facts (Koscinski \& Gast, 1993) and spelling words (Stevens et al., 1991) can be taught with CTD and a computer.

There also is growing evidence that for students with achievement problems, computer-assisted instruction can be an effective student-directed tool for initial acquisition of basic skills rather than just for practice and drill. Computerassisted-instruction has been demonstrated to be an effective tool for teaching students with learning disabilities how to use a seven-step problem-solving strategy to compute the answer to basic word problems (Shiah, Mastropieri, Scruggs, \& Fulk, 1994-1995).

Three variations of computer programs were effective in improving students' scores on on-line tests of problem solving. The students maintained improvement in problem solving for delayed follow-up post-tests. Transfer of skills to pencil-and-paper problem solving, however, was limited. In reading, first-grade students trained to use a synthetic phonics program demonstrated improved skills on computerpresented specific reading skills and manipulated phonemes on a phonics task (Torgesen \& Barker, 1995). Beyond this, these students scored higher on word recognition and word analysis measures than did students who used an alternative reading program and those in a control group who spent time on a computerized mathematics program.

\section{Tape Recorder}

The tape recorder offers a useful supplement to studentdirected instruction. Tape recording has the potential to 
provide repetition, much as a teacher might, or to guide students through the instructional steps they need for more complex problem solving. For example, Freeman and McLaughlin (1984) used a tape recorder to teach six highschool students with learning disabilities to read a set of 80 new words. With the tape recorder, students read the words at a rate of 80 words per minute. Progress was measured by plotting correct and error rates, and students were taught how to read the progress charts. All students showed rapid improvement in correct and error rates when they read the words for the teacher.

In a more complex application, students used the tape recorder to provide an overt description of the instructional steps to be followed in solving mathematics problems (Wood, Rosenberg, \& Carran, 1993). Three elementaryaged students with learning disabilities were taught the steps to solve mathematics problems by having the teacher model the solution steps while using self-instruction, taping the instructions, and then using the tape to solve additional problems. The students, in collaboration with the teacher, wrote the steps for solving the problems, recorded the steps, and then solved problems using their own taped instructions. After a second training session, all students solved problems correctly when using the taped self-instructions and later without the taped instructions. Students who had only observed the process were unable to solve math problems correctly.

Although neither study was conducted in a general education classroom, both raise some interesting possibilities. Teachers have used the tape recorder for years in special education classes as an alternative means for presenting and reviewing sight words, math facts, spelling words, and other rote memory tasks (e.g., Freeman and McLaughlin, 1984). Microcassette recorders with earphones provide an alternative that could be employed more widely in general education classes.

Even more intriguing is the possibility of using a student's taped self-instructions as a form of covert self-talk and to promote a clear, specific routine (Christenson et al., 1989). This technique also can assist in solving arithmetic problems (Wood, et al., 1993), effectively using a textbook, or guiding a student through proofreading written work.

\section{SOME FINAL THOUGHTS}

Our goal for students with mild disabilities is to lead them from reliance on the more supportive, teacher-directed environment (teacher-directed strategies) to one in which they learn to become responsible for managing their own learning and behavior (student-directed strategies). We think every teacher of students with disabilities, whether a special educator or general educator, has to be able to see the big picture of how the curriculum, teaching methods, and setting for delivering the instruction ultimately will lead to greater independence for our students. The structure and support of effective teacher-directed interventions, such as advanced organizers and story maps, provide the groundwork and model for beginning support in an inclusion setting and as the foundation for student-directed procedures.

\section{REFERENCES}

Adams, G. L., \& Engelmann, S. (1996). Research on direct instruction: Twenty-five years beyond DISTAR. Seattle: Educational Achievement Systems.

Adelman, H. S., \& Taylor, L. (1993). Learning problems \& learning disabilities: Moving forward. Pacific Grove, CA: Brooks/Cole.

Alberto, P. A., Jobes, N., Sizemore, A., \& Doran, D. (1980). A comparison of individual and group instruction across response tasks. Journal of the Association for the Severely Handicapped, 5, 259-293.

Anderson, D. M., \& Keel, M. C. (in press). Using reasoning and writing to teach writing skills to students with learning disabilities and behavioral disorders. Effective School Practices.

Ausubel, D. P., Novak, J. D., \& Hanesian, H. (1978). Educational psychology: A cognitive view ( $2 \mathrm{~d}$ ed.). New York: Holt, Rinehart and Winston.

Baker, J. M., \& Zigmond, N. (1995). The meaning and practice of inclusion for students with learning disabilities: Themes and implications from the five cases. Journal of Special Education, 29, 163-180.

Beck, R., Conrad, D., \& Anderson, P. (1995). Basic skill builders handbook. Longmont, CO: Sopris West.

Bender, W, N., \& Ukeje, I. C. (1989). Instructional strategies in mainstream classrooms: Predictions of strategies teachers select. Remedial \& Special Education, 10 (2), 23-30.

Blick, D. W., \& Test, D. W. (1987). Effects of self-recording on high school students' on-task behavior. Learning Disability Quarterly, 10, 203-213.

Borkowski, J. G., \& Thorpe, P. K. (1994). Self-regulation and motivation: A lifespan perspective on underachievement. In D. H. Schunk \& B. J. Zimmerman (Eds.), Self-regulation learning and performance: Issues and educational applications (pp. 45-73). Hillsdale, NJ: Erlbaum.

Browder, D. M., Schoen, S. F., \& Lenz, F. E. (1986-1987). Learning to learn though observation. Journal of Special Education, 20, 447-461.

Brown, A. L. (1994). The advancement of learning. Educational Researcher, $23(8), 4-12$.

Buggey, T. (1999). "Look! I'm on TV": Using videotaped self-modeling to change behavior. Teaching Exceptional Children, 31 (4), 27-30.

Bulgren, J., Schumaker, J. B., \& Deshler, D. D. (1988). Effectiveness of a concept teaching routine in enhancing the performance of LD students in secondary-level mainstream classes. Learning Disabilities Quarterly, 11, 3-17.

Carnine, D. W., Silbert, J., \& Kameenui, E. J. (1997). Direct instruction reading ( $3 \mathrm{~d}$ ed.). Columbus, $\mathrm{OH}$ : Merrill.

Chall, J. S. (1988). Stages of reading development. New York: Academic Press.

Christenson, S. L., Ysseldyke, J. E., and Thurlow, M. L. (1989). Critical instructional factors for students with mild handicaps: An integrated review. Remedial \& Special Education, 10 (5), 21-31.

Clees, T. (1994-95). Self-recording of students' daily schedules of teachers' expectancies: Perspectives on reactivity, stimulus control, and generalization. Exceptionality, 5, 113-129.

Danoff, B., Harris, K., \& Graham, S. (1993). Incorporating strategy instruction within the writing process in the regular classroom: Effects on the writing of students with and without learning disabilities. Journal of Reading Behavior, 25, 295-322. 
Darch, C. (1989). Comprehension instruction for high school learning disabled students. Research in Rural Education, 5, 43-49.

Darch, C., \& Carnine, D. W. (1986). Teaching content area material to learning disabled students. Exceptional Children, 53, 240-246.

Darch, C., \& Gersten, R. (1986). Direction-setting activities in reading comprehension: A comparison of two approaches. Learning Disability Quarterly, 9, 235-243.

Delquadri, J., Greenwood, C. R., Whorton, D., Carta, J. J., \& Hall, R. V. (1986). Classwide peer tutoring. Exceptional Children, 52, 535-542.

DiGangi, S., \& Maag, J. (1992). A component analysis of self-management training with behaviorally disordered youth. Behavioral Disorders, 17 , 281-290.

DiGangi, S., Maag, J., \& Rutherford, R. (1991). Self-graphing of on-task behavior: Enhancing the reactive effects of self-monitoring on on-task behavior and academic performance. Learning Disability Quarterly, 14, 221-229.

Dunlap, L. K., \& Dunlap, G. (1989). A self-monitoring package for teaching subtraction with regrouping to students with learning disabilities. Journal of Applied Behavior Analysis, 22, 309-314.

Edwards, B., Blackhurst, A., \& Koorland, M. (1995). Computer-assisted constant time delay prompting to teach abbreviation spelling to adolescents with mild learning disabilities. Journal of Special Education Technology, 12, 302-310.

Ellis, E. S. (1994). An instructional model for integrating content-area instruction with cognitive strategy instruction. Reading \& Writing Quarterly, 1, 63-90.

Fisher, J., Schumaker, J., \& Deshler, D. (1996). Searching for validated inclusive practices: A review of the literature. Focus on Exceptional Children, 28 (4). 1-20.

Fredrick, L. D., Keel, M. C., and Neel, J. H. (in press). Making the most of instructional time: Teaching reading at an accelerated rate to students placed at risk. Manuscript submitted for publication.

Freeman, T. J., \& McLaughlin, T. F. (1984). Effects of a taped-words treatment procedure on learning disabled students' sight-word oral reading. Learning Disability Quarterly, 7, 49-54.

Fuchs, D., Fuchs, L. S., Mathes, P. G., \& Simmons, D. C. (1997). Peerassisted learning strategies: Making classrooms more responsive to academic diversity. American Educational Research Journal, 34, 174-206.

Fuchs, L., Fuchs, D., Hamlett, C., Phillips, N., \& Karns, K. (1995). General educators' specialized adaptation for students with learning disabilities. Exceptional Children, 61, 440-459.

Garner, R. (1992). Self-regulated learning, strategy shifts, and shared expertise: Reactions to Palincsar and Klenk. Journal of Learning Disabilities, 5, 226-229.

Gast, D. L., Doyle, P. M., Wolery, M., Ault, M. J., \& Baklarz, J. L. (1991). Acquisition of incidental information during small group instruction. Education \& Treatment of Children, 14, 1-18.

Gersten, R. (1998). Recent advances in instructional research for students with learning disabilities: An overview. Learning Disabilities Research and Practice, 13, 162-170.

Graham, S. (1990). The role of production factors in learning disabled students' compositions. Journal of Educational Psychology, 82, 781-791.

Graham, S., \& Harris, K. R. (1989). Improving learning disabled students' skills at composing essays: Self-instructional strategy training. Exceptional Children, 56, 201-214.

Graham, S., \& Harris, K. (1994). The role and development of self-regulation in the writing process. In D. H. Schunk and B. J. Zimmerman (Eds.), Self-regulation of learning and performance: Issues and educational applications (pp. 203-228). Hillsdale, NJ: Erlbaum.

Graham, S, Harris, K. R., MacArthur, C. A., \& Schwartz, S. (1991). Writing and writing instruction for students with learning disabilities: Review of a research program. Learning Disabilities Quarterly, 14, 89-114.
Graham, S., Harris, K. R., \& Reid, R. (1993). Developing self-regulated learners. In E. L. Meyen, G. A. Vergason, \& R. J. Whelan (Eds.), Educating students with mild disabilities (pp. 127-149). Denver: Love.

Graham, S., MacArthur, C., \& Schwartz, S. (1995). Effects of goal setting and procedural facilitation on the revising behavior and writing performance of students with writing and learning problems. Journal of Educational Psychology, 87, 230-240.

Greenwood, C. (1991). Longitudinal analysis of time, engagement, and achievement in at-risk versus non-risk students. Exceptional Children, 521-533.

Greenwood, C. R., Delquadri, J., \& Hall, R. V. (1989). Longitudinal effects of classwide peer tutoring. Journal of Educational Psychology, 81, 371-383.

Harper, G., Mallette, B., Maheady, L., Parkes, V., and Moore, J. (1993). Retention and generalization of spelling words acquired using a peermediated instructional procedure by children with mild handicapping conditions. Journal of Behavioral Education, 3, 25-38.

Hirsh, E. D. (1996). The schools we need and why we don't have them. New York: Doubleday.

Hughes, C., Korinek, L., \& Gorman, J. (1991). Self-management for students with mental retardation in public school settings: A research review. Education \& Training in Mental Retardation, 26, 271-291.

Idol, L. (1987). Group story mapping. A comprehensive strategy for both skilled and unskilled readers. Journal of Learning Disabilities, 20 , 196-205.

Idol, L., \& Croll, V. J. (1987). Story-mapping training as a means of improving reading comprehension. Learning Disability Quarterly, 10, 214-229.

Idol-Maestas, L. (1985). Getting ready to read: Guided probing for poor comprehenders. Learning Disability Quarterly, 8, 243-254.

Johnson, K. R. (1989). Executive summary. Seattle: Morningside.

Johnson, D. W., \& Johnson, R. T. (1986). Mainstreaming and cooperative learning strategies. Exceptional Children, 52, 553-562.

Johnson, L. R., \& Johnson, C. E. (1999). Teaching students to regulate their own behavior. Teaching Exceptional Children, 10 (4), 6-10.

Kaiser, S., Palumbo, K., Bialozor, R. C., \& McLaughlin, T. F. (1989). The effects of direct instruction with rural remedial education students: A brief report. Reading Improvement, 26, 88-93.

Kameenui, E. J. (1985). Direct instruction of reading comprehension: Beyond teacher performance variables to the design of instruction. In J. Niles \& R. Lalik (Eds.), Thirty-fourth yearbook of the National Reading Conference, Issues in Literacy; A research perspective (pp. 257-262). Rochester, NY: National Reading Conference.

Keel, M. C., \& Gast, D. L. (1992). Small-group instruction for students with learning disabilities: Observational and incidental learning. Exceptional Children, 58, 357-368.

Kelly, B., Gersten, R., \& Carnine, D. (1990). Student error patterns as a function of instructional design: Teaching fractions to remedial high school students and high school students with disabilities. Journal of Learning Disabilities, 23, 23-29.

King-Sears, M. E., Mercer, C. D., \& Sindelar, P. T. (1992). Toward independence with keyword mnemonic: A strategy for science vocabulary instruction. Remedial \& Special Education, 13 (5), 22-33.

Kochhar, C. A., \& West, L. L. (1996). Handbook for successful inclusion. Fredrick, MD: Aspen.

Koscinski, S. T., \& Gast, D. L. (1993). Use of constant time delay in teaching multiplication facts to students with learning disabilities. Journal of Learning Disabilities, 26, 533-567.

Kuder, S. J. (1990). Effectiveness of the DISTAR reading program for children with learning disabilities. Journal of Learning Disabilities, 23, 69-71. 
Kuder, S. J. (1991). Language abilities and progress in a direct instruction reading program for students with learning disabilities. Journal of Learning Disabilities, 14, 124-127.

Lawrence, P. A. (1988). Basic strategies for mainstream integration. Academic Therapy, 23, 349-355.

Lenz, B. K., Alley, G. R., \& Schumaker, J. B. (1987). Activating the inactive learner: Advance organizers in the secondary content classroom. Learning Disability Quarterly, 10, 53-67.

Lenz, B. K., Schumaker, J. B., Deshler, D. D., \& Beals, V. L. (1984). The learning strategy curriculum: The word identification strategy. Lawrence: University of Kansas.

Lindsley, O. R. (1991). Precision teaching's unique legacy from B. F. Skinner. Journal of Behavioral Education, 2, 253-266.

Lloyd, J., Cullinan, D., Heins, E. D., \& Epstein, M. H. (1980). Direct instruction: Effects on oral and written comprehension. Learning Disabilities Quarterly, 3, 70-76.

Lovitt, T., Rudsit, J., Jenkins, J., Pious, C., \& Benedetti, D. (1985). Two methods of adapting science materials for learning disabled and regular seventh graders. Learning Disabilities Quarterly, 8, 275-285.

Lum, T., \& Morton, L. L. (1984). Direct instruction in spelling increases gain in spelling and reading skills. Special Education in Canada, 58, $41-45$.

Mace, F. C., Belfiore, P. J., \& Shea, T. M. (1990). A collateral effect of reward predicted by matching theory. Journal of Applied Behavior Analysis, 23, 197-205.

Maloney, M., \& Humphrey, J. E. (1982). The Quinte Center: A successful venture in behavioral education. Behavioral Educator, 4(1), 1-3.

Martens, B. K., Peterson, R. L., Witt, J. C., \& Circone, S. (1986). Teacher perceptions of school-based interventions. Exceptional Children, 53, 213-223.

Mathes, P. G., Grek, M. L., Howard, J. K., Babyak, A. E., \& Allen, S. H. (1999). Peer-assisted learning strategies for first-grade readers: A tool for preventing early reading failure. Learning Disabilities Research \& Practice, 14, 50-60.

McCoy, K. M. (1995). Teaching special learners in the general education classroom: Methods and techniques (2d ed.). Denver: Love.

McLaughlin, T. F., Krappman, V. F., \& Welsh, J. M., (1985). The effects of self-recording for on-task behavior of behaviorally disordered special education students. Remedial \& Special Education, 6, 42-45.

McLeskey, J., Henry, D., \& Hodges, D. (1998). Inclusion: Where is it happening? Teaching Exceptional Children, 31 (1), 4-10.

Mercer, C. D., \& Mercer, A. R. (1998). Teaching students with learning problems (5th ed.). New York: Merrill/Macmillan.

Meyen, E. L., Vergason, G. A., \& Whelan, R. J. (Eds.) (1996). Strategies for teaching exceptional children in inclusive settings. Denver: Love.

Montague, M. (1991). The effects of cognitive and metacognitive strategy instruction on the mathematical problem solving of middle school students with learning disabilities. Journal of Learning Disabilities, 25, 230-242.

Montague, M., Applegate, B., \& Marquard, K. (1993). Cognitive strategy instruction and mathematical problem-solving performance of students with learning disabilities. Learning Disabilities Research \& Practice, 8, 223-232.

Nelson, J. R., Smith, D. J., Young, R. K., \& Dodd, J. M., (1991). A review of self-management outcome research conducted with students who exhibit behavioral disorders. Behavioral Disorders, 16, 169-179.

Okolo, C. M. (1992). The effects of computer-based attribution retraining on the attributions, persistence, and mathematics computation of students with learning disabilities. Journal of Learning Disabilities, 25, 327-334.

Osborne, S. S., Kosiewicz, M. M., Crumley, E. B., \& Lee, C. (1987). Distractible students use self-monitoring. Teaching Exceptional Children, 19 (2), 66-69.
Palincsar, A., \& Brown, A. (1984). Reciprocal teaching of comprehensionfostering and comprehension-monitoring activities. Cognition \& Instruction, 2, 117-175.

Peck, G. (1989). Facilitating cooperative learning: A forgotten tool gets it started. Academic Therapy, 25, 145-150.

Phillips, N. B., Hamlett, C. L., Fuchs, L. S., \& Fuchs, D. (1993). Combining classwide curriculum-based measurement and peer tutoring to help general educators provide adaptive education. Learning Disabilities Research \& Practice, 8, 148-156.

Prater, M. A., Joy, R., Chilman, B., Temple, J., \& Miller, S. (1991). Selfmonitoring of on-task behavior by adolescents with learning disabilities. Learning Disability Quarterly, 14, 164-177.

Reynolds, C. J., \& Salend, S. J. (1990). Teacher-directed and student-mediated comprehension strategies. Academic Therapy, 25, 417-427.

Robinson, J. W., \& Hesse, K. D. (1981). A morphemically based spelling program's effect on spelling kills and spelling performance of seventh grade students. Journal of Educational Research, 75, 56-62.

Schumaker, J. B., Deshler, D. D., \& Denton, P. H. (1984). The learning strategy curriculum: The paraphrasing strategy. Lawrence: University of Kansas.

Schunk, D. H., \& Zimmerman, B. J. (Eds.). (1994). Self-regulation learning and performance: Issues and educational applications. Hillsdale, NJ: Erlbaum.

Shelton, B. S., Gast, D. L., Wolery, M., \& Winterling, V. (1991). The role of small group instruction in facilitating observational and incidental learning. Language, Speech, and Hearing Services in Schools, 22, $123-133$.

Shiah, R. L., Mastropieri, M., Scruggs, T.E., \& Fulk, B.J. (1994-1995). The effects of computer-assisted instruction on the mathematical problem solving of students with learning disabilities. Exceptionality, 5, 131-161.

Siegler, R. S. (1995). How does change occur? A microgenetic study of number conservation. Cognitive Psychology, 28, 225-273.

Slavin, R. E. (1990). Cooperative learning: Theory, research and practice. Englewood Cliffs, NJ: Prentice Hall.

Sorrell A. L. (1990). Three reading comprehension strategies: TELLS, story mapping, and QARs. Academic Therapy, 25, 359-368.

Spekman, N. J., Goldberg, R. J., \& Herman K. L. (1992). Learning disabled children grow up: A search for factors related to success in the young adult years. Learning Disabilities Research and Practice, 7, 161-170.

Stainback, S., \& Stainback, W. (Eds.). (1990). Support networks for inclusive schools: Interdependent integrated education. Baltimore: Paul $\mathrm{H}$. Brooks.

Stainback, W., \& Stainback, S. (Eds.). (1992). Curriculum considerations in inclusive classrooms: Facilitating learning for all students. Baltimore: Paul H. Brooks.

Stainback, S., \& Stainback, W. (Eds.). (1996). Inclusion: A guide to educators. Baltimore: Paul H. Brooks.

Stein, M., Silbert, J., \& Carnine, D. (1997). Designing effective mathematics instruction: A direct instruction approach ( $3 \mathrm{~d}$ ed.). Columbus, $\mathrm{OH}$ : Merrill.

Stevens, K. B., Blackhurst, A. E. \& Slaton, D. B. (1991). Teaching memorized spelling with a microcomputer: Time delay and computerassisted instruction. Journal of Applied Behavior Analysis, 24, 153-160.

Stump, C. S., Lovitt, T. C., Fister, S., Kemp, K., Moore, R., \& Schroeder, B. (1992). Vocabulary intervention for secondary-level youth. Learning Disability Quarterly, 15, 207-222.

Tarver, S. G., \& Jung, J. S. (1995). A comparison of mathematics achievement and mathematics attitudes of first and second graders instructed with either a discovery-learning mathematics curriculum or a direct instruction curriculum. Effective School Practices, 14, 49-57. 
Thousand, J. S., Villa, R. A., \& Nevin, A. I. (Eds.). (1994). Creativity and collaborative learning: A practical guide to empowering students and teachers. Baltimore: Paul H. Brooks.

Torgesen, J. K., \& Barker, T. A. (1995). Computers as aids in the prevention and remediation of reading disabilities. Learning Disability Quarterly, 18, 76-86.

Torgesen, J. K., Waters, M. D., Cohen, A. L., \& Torgesen, J. L. (1988). Improving sight-word recognition skills in LD children: An evaluation of three computer program variations. Learning Disability Quarterly, $11,125-132$.

Vergason G. A., \& Anderegg, M. L. (1991). Beyond the regular education initiative and the resource room controversy. Focus on Exceptional Children, 23 (7), 1-7.

Villa, R. A., Thousand, J. S., Stainback, W., \& Stainback, S. (Eds.). (1992). Restructuring for caring and effective education: An administrative guide to creating heterogeneous schools. Baltimore: Paul $\mathrm{H}$. Brooks.

Wang, M. C. (1992). Adapting education strategies: Building on diversity. Baltimore: Paul H. Brooks.

Welch, M. (1992). The PLEASE strategy: A metacognitive learning strategy for improving the paragraph writing of students with learning disabilities. Learning Disabilities Quarterly, 15, 119-128.

Werner, E. E. (1993). Risk and resilience in individuals with learning disabilities: Lessons learned from the Kauai longitudinal study. Learning Disabilities Research and Practice, 8, 28-34.

Whinnery, K. W., Fuchs, L. S., \& Fuchs, D. (1991). General, special, and remedial teachers' acceptance of behavioral and instructional strategies for mainstreaming students with mild handicaps. Remedial \& Special Education, 12, (4), 6-17.

Winterling, V. (1990). The effects of constant time delay, practice in writing or spelling, and reinforcement on sight word recognition in a small group. Journal of Special Education, 24, 101-116.

Wirtz, C. L., Gardner, R., Weber, K., \& Bullara, D. (1996). Using self-correction to improve spelling performance of low-achieving third graders. Remedial \& Special Education, 17 (1), 48-58.
Wolery, M., Ault, M. J., \& Doyle, P. M. (1992). Teaching students with moderate to severe disabilities. White Plains, NY: Longman.

Wolery, M., Ault, M. J., Gast, D. L., Doyle, P. M., \& Mills, B. M. (1990). Use of choral and individual spelling attentional responses in teaching sight word reading during small group instruction. Remedial \& Special Education, 11 (5), 47-58.

Wolery, M., Cybriwsky, C. A., Gast, D. L., \& Boyle-Gast, K. (1991). Use of constant time delay and attentional responses in adolescents. Exceptional Children, 57, 462-474.

Wolery, M., Holcombe, A., Cybriwsky, C., Doyle, P. M., Schuster, J. W., Ault, M. J., \& Gast, D. L. (1992). Constant time delay with discrete responses: A review of effectiveness and demographic, procedural, and methodological parameters. Research in Developmental Disabilities, 13, 239-266.

Wong, B. Y. L. (1996). ABCs of learning disabilities. San Diego: Academic Press.

Wong, B. Y. L., \& Jones, W. (1982). Increasing metacomprehension in learning disabled and normally achieving students through self-questioning training. Learning Disabilities Quarterly, 5, 228-239.

Wood, D. A., Rosenberg, M. S., \& Carran, D. T. (1993). The effects of taperecorded self-instruction cues on the mathematics performances of students with learning disabilities. Journal of Learning Disabilities, 26, 250-258.

Zigmond, N., Jenkins, J., Fuchs, L. S., Deno, S., Fuchs, D., Baker, J., Jenkins, L., \& Couthino, M. (1995). Special education in restructured schools: Findings from three multi-year studies. Phi Delta Kappan, 76, $531-540$.

Zionts, P. (Ed). (1997). Inclusion strategies for students with learning and behavior problems. Austin, TX: Pro-Ed.

\section{PERMISSIONS AND COPYRIGHT}

All rights are reserved. No part of this publication may be reproduced, photocopied, faxed, stored in a retrieval system, or transmitted in any form or by any means, electronic, mechanical, recording or otherwise, without the prior written permission of the publisher.
Back issues are available for sale. Reproduction requires permission and payment of fees. It is illegal and a violation of federal copyright law to reproduce this publication without permission. Direct all inquiries to the permissions editor. 